\title{
YOGA TAHAP I MAMPU MENINGKATKAN FLEXIBILITAS OTOT PADA REMAJA PUTRI DI SANGGAR SENAM STUDIO 88 DENPASAR
}

\author{
Ni Putu Wiwik Oktaviani ${ }^{1}$, Ni Kadek Yuni Lestari ${ }^{2}$ \\ Sekolah Tinggi Ilmu Kesehatan Wira Medika, Jl.Kecak No. 9A, Bali \\ E-mail: oktaviani.wiwik@yahoo.com
}

\begin{abstract}
ABSTRAK
Overweight menjadi salah satu masalah kesehatan remaja di Indonesia. Latihan yang bersifat aerobik dapat menurunkan lemak tubuh, mencegah overweight dan meningkatkan fleksibilitas. Tujuan penelitian ini untuk mengetahui hatha yoga dapat meningkatkan fleksibilitas pada remaja putri di Denpasar. Rancangan penelitian randomized with pre-test and post-test group design. Kelompok (13 sampel) mendapat perlakuan hatha yoga. Perlakuan diberikan selama 6 minggu, frekuensi 3 kali/minggu, durasi 45 menit di Sanggar Senam Studio 88 Denpasar pada pagi hari. Hasil penelitian menunjukkan peningkatan fleksibilitas hatha yoga dengan rerata $12,58 \mathrm{~cm}$. Hasil rerata peningkatan fleksibilitas sebesar $5 \mathrm{~cm}$ dengan nilai $p=0,035$. Simpulan bahwa pelatihan hatha yoga efektif dalam menurunkan persentase lemak tubuh dan meningkatkan fleksibilitas di Denpasar. Kepada individu dengan overweight sebaiknya melakukan aktivitas olahraga secara rutin dan kontinyu. Hatha Yoga sebagai salah satu alternatif kegiatan olahraga yang dapat digunakan untuk meningkatkan fleksibilitas serta kebugaran fisik.
\end{abstract}

Kata Kunci : Hatha yoga, fleksibilitas

\section{ABSTRACT}

Overweight was one of the adolescent health problem in Indonesia. Aerobic exercise can reduce body fat, prevent overweight and increase flexibility. The purpose of this study was to identify the effect of Hatha Yoga flexibility of adolescent girl in Denpasar. Research used randomized pre-test and post-test design involved 26 subject. Group treated hatha yoga. This intervention was given for 6 weeks, frequency 3 times a week, for 45 minute in Sanggar Senam Studio 88 Denpasar. The result shown that hatha yoga increasing of flexibility hatha yoga with a mean $12.58 \mathrm{~cm}$. The result mean increased flexibility by $5 \mathrm{~cm}$ with value of $p=0.035$. Conclusion: hatha yoga effective increasing flexibility of adolescent girl in Denpasar. It is suggested to individuals with overweight in order to do sports activities regularly and continuously. Hatha yoga as an alternative sport activities that can be used to increase flexibility and physical fitness.

Keyword: Hatha Yoga, flexibility

\section{PENDAHULUAN}

Usia harapan hidup merupakan salah satu indikator yang digunakan untuk mengelompokkan negara dalam kelompok negara maju atau berkembang. Negara

\footnotetext{
${ }^{1}$ Ni Putu Wiwik Oktaviani, S.Kep.,Ns., M.Kep : Dosen STIKes Wira Medika

${ }^{2}$ Ni Kadek Yuni Lestari, S.Kep.,Ns., M.Fis : Dosen STIKes Wira Medika
} 
maju relatif memiliki usia harapan hidup yang tinggi, sedangkan negara berkembang memiliki usia harapan hidup relatif rendah. Usia harapan hidup juga merupakan ukuran kualitas atau kemakmuran hidup di suatu negara, (Tempo, 2013). Indonesia sendiri berada diurutan ke 137 di dunia dan angka usia harapan hidup tertinggi yaitu di Negara Monako sebesar 89,73 tahun. Berdasarkan Badan Pusat Statistik tahun 2010-2015 menyebutkan bahwa angka harapan hidup untuk Indonesia adalah sebesar 70,1 tahun dimana angka ini mengalami peningkatan dari sebelumnya yaitu 69,1 tahun. Peningkatan angka harapan hidup tersebut menyebabkan meningkatnya jumlah populasi penduduk terutama populasi penduduk lanjut usia, (Tempo, 2013).

Meningkatnya angka harapan hidup menunjukkan perbaikan kesehatan masyarakat. Kehidupan yang sehat merupakan faktor penting agar setiap individu dapat melakukan aktivitas sehari-hari. Untuk mencapai kehidupan yang sehat dan produktif, setiap individu memerlukan kondisi fisik yang optimal. Kondisi fisik yang optimal salah satunya dipengaruhi oleh kebugaran fisik. Kebugaran fisik yang baik maka seseorang mampu melakukan aktivitas fisik dalam pekerjaan sehari-hari tanpa menimbulkan kelelahan fisik yang berlebihan dan masih dapat melakukan kegiatan lainnya, (Nurhasan, 2005).

International Journal of Cardiology (Holger Cramer a, 2014) dengan judul Effects Of Yoga On Cardiovascular Disease Risk Factors mendapatkan hasil bahwa yoga dapat menstabilkan tekanan darah, denyut jantung, meningkatkan daya tahan kardiorespirasi, mengurangi obesitas, menstabilkan lemak darah dan peningkatan resistensi terhadap insulin pada pasien diabetes mellitus. Di Indonesia, senam yoga mulai dikenal tahun 90-an. Dalam delapan tahun terakhir ini, perkembangan tempat untuk berlatih yoga atau yoga center di Indonesia meningkat dengan pesat. Animo masyarakat untuk beryoga menunjukkan grafik yang meningkat. Sebagai olah seni dan jiwa, yoga mengkombinasikan pengendalian pikiran dan pernapasan dengan latihan fisik. Gerakannya cenderung halus dan tidak terburu-buru. Banyak yang masih beranggapan bahwa senam yoga hanyalah sekadar meregangkan otot semata. Padahal, meskipun peregangan otot memang dibutuhkan, namun yoga sebenarnya berusaha menciptakan keselarasan dalam tubuh melalui peningkatan fleksibilitas dan kekuatan otot.

Pelatihan yoga secara teratur akan berdampak terhadap penambahan panjang otot yang biasanya dihasilkan dari pertambahan sarkomer (unit mendasar dari serabut otot) pada 7 serat otot, terutama pada daerah myotendinnous junction (daerah pertemuan otot dengan tendon). Jika unit tendon-otot renggang, sarkomer tambahan akan ditambahkan secara khas pada daerah tersebut. Pada daerah sendi, seperti meningkatnya elastisitas ligamen dan kapsul sendi yang merupakan penghubung antara tulang dan tulang sehingga ruang gerak sendi menjadi lebih luas, meningkatkan kekuatan kapsul sendi untuk membungkus cairan synovial sehingga pergerakan sendi tidak terganggu dan menjadi lebih luas, dan menjaga cairan synovial yang berfungsi sebagai pelumas dari sendi. Peningkatan adaptasi dari otot dan sendi yang terjadi saat diberikan pelatihan yoga secara teratur akan meningkatkan kelentukan (Mertayasa, 2013).

Hasil studi pendahuluan yang dilakukan terhadap 10 orang remaja putri mengenai Flexibilitas otot diukur dengan Standing Trunk Flexion didapatkan hasil 5 orang dengan flexibilitas otot kurang dan 5 orang dengan flexibilitas otot cukup. 
Berdasarkan masalah tersebut peneliti melakukan penelitian Efektifitas Yoga Tahap I terhadap Flexibilitas Otot Pada Remaja Putri.

\section{METODE}

Penelitian ini menggunakan pre-test and post-test with control group design. Populasi dalam penelitian ini adalah remaja putri yang berjumlah 147 orang. Sampel dalam penelitian ini adalah populasi yang memenuhi kriteria inklusi dan eksklusi. Jumlah sampel dalam penelitian dihitung dengan menggunakan rumus Pocock sebesar 26 responden dengan asumsi Drop Out 20\%.

Kriteria Inklusi Remaja putri rentang umur 19-21 tahun, Tidak pernah melakukan olahraga secara rutin, Memiliki IMT > 22,5, Bersedia menjadi subjek penelitian dari awal hingga akhir penelitian dengan menandatangani informed consent

\section{HASIL}

Tabel 5.1 Karakteristik Responden Kelompok 1 dan Kelompok 2

\begin{tabular}{lccc}
\hline $\begin{array}{l}\text { Karakteristik } \\
\text { Responden }\end{array}$ & $\mathrm{n}$ & Kelompok 1 & Kelompok 2 \\
& & & (Hatha Yoga) \\
Low Impact)
\end{tabular}

\begin{tabular}{lccc} 
& & rerata \pm SB & rerata \pm SB \\
\cline { 2 - 4 } Umur (tahun) & 13 & $21,15 \pm 0,38$ & $21,46 \pm 21,46$ \\
Tinggi Badan (cm) & 13 & $162,15 \pm 3,87$ & $161,31 \pm 161,31$ \\
Berat Badan (kg) & 13 & $70,08 \pm 11,39$ & $69,38 \pm 69,38$ \\
$\begin{array}{l}\text { Indeks Massa Tubuh } \\
\left(\mathrm{kg} / \mathrm{m}^{2} \text { ) }\right.\end{array}$ & 13 & $26,15 \pm 3,59$ & $26,63 \pm 26,63$ \\
$\begin{array}{l}\text { Asupan Kalori (kkal) } \\
\text { Denyut Nadi }\end{array}$ & 13 & $1256,72 \pm 247,89$ & $1275,21 \pm 1275,21$ \\
(kali/menit) & 13 & $96,43 \pm 5,04$ & $107,23 \pm 10,58$ \\
\hline
\end{tabular}

Tabel 5.2 Uji Normalitas dan Homogenitas Data Persentase Lemak Tubuh dan Fleksibilitas Sebelum dan Setelah Perlakuan

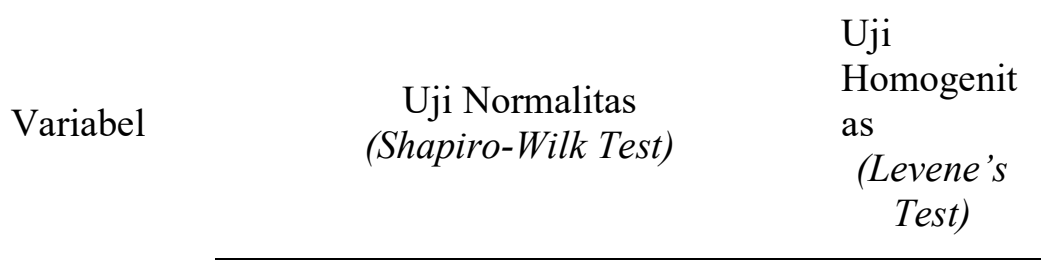




$\begin{array}{cc}\text { Kelompok 1 } & \text { Kelompok } 2 \\ \text { ( Hatha Yoga) } & \text { (Senam } \\ & \text { Aerobik Low } \\ & \text { Impact) }\end{array}$

\begin{tabular}{lccc} 
& $\mathrm{p}$ & $\mathrm{p}$ & $\mathrm{p}$ \\
\cline { 2 - 4 } $\begin{array}{l}\text { Persentase } \\
\text { Lemak Tubuh }\end{array}$ & 0,504 & 0,060 & 0,947 \\
Pre-test & & & \\
$\begin{array}{l}\text { Persentase } \\
\text { Lemak Tubuh }\end{array}$ & 0,346 & 0,062 & 0,884 \\
$\begin{array}{l}\text { Post-test } \\
\text { Fleksibilitas } \\
\text { Pre-test }\end{array}$ & 0,497 & & \\
$\begin{array}{l}\text { Fleksibilitas } \\
\text { Post-test }\end{array}$ & 0,058 & 0,856 & 0,102 \\
& & 0,346 & 0,747 \\
\hline
\end{tabular}

Tabel 5.3

Hasil Uji Beda Fleksibilitas Kelompok 1 (Hatha Yoga) Pre-test dan Post-test

\begin{tabular}{|c|c|c|c|c|c|}
\hline \multirow[b]{2}{*}{ Variabel } & \multirow[b]{2}{*}{$\mathrm{n}$} & Pre-test & Post-test & \multirow[b]{2}{*}{$\mathrm{t}$} & \multirow[b]{2}{*}{$\mathrm{p}$} \\
\hline & & $\begin{array}{c}\text { Rerata } \\
\pm \text { SB }\end{array}$ & $\begin{array}{c}\text { Rerata } \\
\pm \text { SB }\end{array}$ & & \\
\hline Fleksibilitas & 13 & $\begin{array}{c}- \\
2,73 \pm 8,65\end{array}$ & $\begin{array}{c}9,84 \pm 5,7 \\
7 \\
\end{array}$ & $\overline{-}$ & $\begin{array}{c}0,00 \\
1\end{array}$ \\
\hline
\end{tabular}

\section{PEMBAHASAN}

Pengaruh Hatha Yoga terhadap Fleksibilitas pada Remaja Putri Overweight

Berdasarkan hasil penelitian data fleksibilitas pada kelompok perlakuan Hatha Yoga selama 6 minggu didapatkan rerata hasil sebelum perlakuan -2,73 $\pm 8,65$ $\mathrm{cm}$ dan setelah perlakuan $9,84 \pm 5,77 \mathrm{~cm}$. Dilihat dari nilai rerata maka terjadi peningkatan nilai fleksibilitas setelah perlakuan Hatha Yoga sebesar 12,58 cm. Hasil analisis data hipotesis fleksibilitas pre-test dan post-test menggunakan Paired Samples $T$ test diperoleh nilai $\mathrm{p}<0,05$ maka dapat disimpulkan terdapat perbedaan yang bermakna.

Fleksibilitas merupakan kemampuan untuk melakukan gerakan dalam ruang gerak sendi dimana ditentukan oleh elastis tidaknya otot-otot, tendon dan ligamen (Yoda, 2006). Perbaikan fleksibilitas bisa mengurangi kemungkinan cedera pada otot dan sendi, membantu dalam mengembangkan kecepatan, koordinasi dan 
kelincahan, menghemat pengeluaran tenaga pada waktu melakukan gerakan serta membantu mengembangkan prestasi (Mertayasa, 2013).

Pemberian pelatihan Hatha Yoga dengan durasi 45 menit dan frekuensi 3 kali seminggu bermanfaat untuk meningkatkan fleksibilitas. Salah satu bagian dari gerakan Hatha Yoga disebut asana yang bekerja aman untuk stretching otot. Proses ini melepaskan asam laktat yang biasanya menyebabkan kekakuan, ketegangan, sakit dan kelelahan. Selain itu yoga juga meningkatkan berbagai gerakan di sendi dan meningkatkan lubrikasi sendi. Stretch pada yoga tidak hanya untuk otot tapi untuk seluruh sel-sel tubuh seseorang. Adaptasi otot dan sendi setelah diberikan pelatihan Hatha Yoga secara teratur memberikan pengaruh signifikan terhadap peningkatan kelentukan. Berdasarkan hasil penelitian Mertayasa (2013) yang meneliti pengaruh pelatihan yoga asana terhadap kelentukan dan kapasitas vital paru peserta putra ekstrakurikuler yoga SMAN 2 Banjar Tahun Pelajaran 2012/2013 yang berjumlah 30 orang siswa didapatkan hasil bahwa pelatihan yoga asana berpengaruh terhadap peningkatan kelentukan sebesar $5 \mathrm{~cm}$ setelah diberikan latihan selama 4 minggu, 3 kali dalam seminggu.

Secara fisiologis dengan melakukan gerakan Hatha Yoga dengan benar dan teratur akan terjadi penambahan panjang serabut otot yang biasanya dihasilkan dari pertambahan sarkomer (unit mendasar dari serabut otot) pada serat otot, terutama pada daerah myotendinous junction (daerah pertemuan otot dengan tendon). Jika unit tendon-otot renggang, sarkomer tambahan akan ditambahkan secara khas pada daerah tersebut. Pada daerah sendi, seperti meningkatnya elastisitas ligamen dan kapsul sendi yang merupakan penghubung antara tulang dan tulang sehingga ruang gerak sendi menjadi lebih luas, meningkatkan kekuatan kapsul sendi untuk membungkus cairan synovial sehingga pergerakan sendi tidak terganggu dan menjadi lebih luas, dan menjaga cairan synovial yang berfungsi sebagai pelumas dari sendi. Peningkatan adaptasi dari otot dan sendi yang terjadi saat diberikan pelatihan Hatha Yoga secara teratur akan meningkatkan kelentukan (Wiarto, 2013).

KESIMPULAN

Pelatihan Hatha Yoga meningkatkan fleksibilitas pada remaja putri overweight di Denpasar sebesar 12,58 cm.

\section{UCAPAN TERIMA KASIH}

Ucapan terima kasih disampaikan kepada :

responden yang telah membantu dan meluangkan waktu dalam penelitian ini.

\section{DAFTAR PUSTAKA}

Nurhasan. 2005. Petunjuk Praktis Pendidikan Jasmani. Surabaya: Unesa University Press.

Mertayasa, K. 2013. Pengaruh Pelatihan Yoga Asana (Suryanamaskar) terhadap Kelentukan dan Kapasitas Vital Paru.

Cramer, H., Lauche, R., Haller, H., Steckhan, N., Michalsen, A., \& Dobos, G. 2014. Effects of Yoga On Cardiovascular Disease Risk Factors: A Systematic Review

Wiarto, G. 2013. Fisiologi dan Olahraga. Yogyakarta: Graha Ilmu . 
Yoda, I. K. 2006. Buku Ajar Peningkatan Kondisi Fisik. Singaraja: IKIP Negeri: Tidak diterbitkan.

Anonim, 2012. Pelayanan Kesehatan Peduli Remaja. available from http://www.diskes.baliprov.go.id/id/pelayanan-kesehatan-peduli-remaja-PKPR-2

Andini, Elfiannisa Azmy. 2016. "Perbedaan Pengaruh Frekuensi Latihan Senam Aerobik terhadap Penurunan Persentase Lemak Tubuh dan Berat Badan pada Members Wanita di Cakra Sport Club Yogyakarta" (Tesis). Yogyakarta Anonim. 2013. Kementrian Kesehatan RI dalam Majalah Tempo. Jakarta.

Anonim. 2016. Yoga Menurunkan Berat Badan. available from https://willowyslim.blogspot.co.id/2016/10/manfaat-senam-aerobik-danyoga.html

Aprilia, S. 2014. Profil Indeks Massa Tubuh dan VO2 Maksimum pada Mahasiswa Anggota Tapak Suci di Universitas Muhammadyah Surakarta. (Doctoral dissertation) : Universitas Muhammadiyah Surakarta. 